\title{
Salvage and translocation of endangered Santa Cruz long-toed salamander larvae
}

\author{
TERRIS KASTEEN ${ }^{1}$, MARK L. ALLABACK ${ }^{2 *}$, DAVID M. LAABS ${ }^{2}$, \\ CHAD MITCHAM ${ }^{3}, \mathrm{KELLI} \mathrm{CAMARA}^{4}$, AND CHRIS CARIS ${ }^{5}$
}

${ }^{1}$ California Department of Fish and Wildlife, Bay Delta Regional Office, 2825 Cordelia Road, Suite 100, Fairfield, CA 94534, USA

${ }^{2}$ Biosearch Environmental Consulting, PO Box 1220, Santa Cruz, CA 95061, USA

${ }^{3}$ United States Fish and Wildlife Service, Ventura Field Office, 2493 Portola Road, \#B, Ventura, CA 93003, USA

${ }^{4}$ Resource Conservation District of Santa Cruz County, 820 Bay Avenue, Suite 136, Capitola, CA 95010, USA

${ }^{5}$ United States Fish and Wildlife Service, San Francisco Bay National Wildlife Refuge System, 1 Marshlands Rd, Fremont, CA 94555, USA

*Corresponding Author: markallaback@sbcglobal.net

Key words: Ambystoma macrodactylum croceum, connectivity, habitat fragmentation, larvae, metamorphosis, oak woodland, Santa Cruz long-toed salamander, translocation

Like many biphasic amphibians that migrate between non-breeding upland and aquatic breeding locations, the endangered Santa Cruz long-toed salamander (Ambystoma macrodactylum croceum) is susceptible to the effects of habitat loss, alteration, and fragmentation (Bury and Ruth 1972; USFWS 1978; Stebbins and McGinnis 2012). The subspecies is particularly imperiled due to its restricted range within a heavily populated landscape in southwest Santa Cruz County and extreme northwest Monterey County (Bury and Ruth 1972; Bury et al. 1980; USFWS 1999; Stebbins and McGinnis 2012). Threats to survival and recovery include ongoing modification or loss of upland habitat and increased barriers to terrestrial movements during migration and dispersal (Bury and Ruth 1972; Allaback and Laabs 2003). Typical barriers include houses and related infrastructure including retaining walls, busy roads, vertical curbs, and solid fences that extend below grade. In many instances, these barriers prevent or severely reduce access between breeding ponds and surrounding upland habitat, while also forcing individuals to navigate converted grasslands and/or other unsuitable terrain (Bury and Ruth 1972).

The range of the subspecies in Santa Cruz County was reported to be approximately 7,580 ha (USFWS 1999), but many areas do not provide suitable habitat and A. m. croceum 
likely inhabits less than half of the remaining available area, much of which is under private ownership subdivided into several hundred parcels (T. Kasteen, personal observation). This remaining habitat is mostly rural-residential embedded in hilly topography (Bury and Ruth 1972), and access to homes often requires long driveways and substantial vegetation clearing for fire safety, which negatively affects $A$. $m$. croceum especially during migration and dispersal. A small number of breeding sites are protected and managed for the subspecies, while most are on private property and inaccessible to determine species presence (C. Mitcham, personal observation).

Ambystoma $\mathrm{m}$. croceum was originally listed as endangered by the federal government in 1967, and although a recovery plan was subsequently approved and critical habitat proposed, it was based on only two known locations (USFWS 1977, 1978). A revised draft recovery plan adopted in 1999 put forth a more comprehensive management strategy (USFWS 1999), but a revision is necessary based on data collected over the last 20 years. Since the mid-2000s, both the California Department of Fish and Wildlife, which considers the subspecies fully protected and endangered, and the United States Fish and Wildlife Service have conserved and enhanced acreage to support recovery actions. The subspecies $A$. $m$. croceum is isolated from other subspecies by more than $240 \mathrm{~km}$ and genetic analysis suggests that full species status may be warranted (USFWS 1978; Savage 2008). Efforts to identify and conserve adequate movement corridors between existing protected lands and undeveloped uplands are ongoing, since the best available genetic data indicates that the groups of populations in Santa Cruz County may be described as two or three subpopulations (W. Savage, University of Massachusetts Lowell, unpublished data). A. m. croceum breeding populations in Santa Cruz County were likely fragmented by the construction and subsequent expansion of State Route 1 and areas disturbed by human development in the coastal zone (USFWS 1999, 2019). Extensive agricultural and residential development for many decades has isolated the Santa Cruz County population from the few scattered locations that still support the subspecies in north coastal Monterey County (C. Mitcham, personal observation). In Monterey County, A. m. croceum faces extirpation/extinction (Bury and Ruth 1972; USFWS 1978), and active management (USFWS 2019) is likely necessary, such as captive rearing to restore genetic variability if inbreeding is prevalent, and/or translocation of eggs or larvae to suitable breeding sites in the remaining oak woodlands east of Elkhorn Slough (C. Mitcham and K. Camara, personal observation).

Conservation biologists have understandably debated concerns that translocation may stress individuals or negatively affect a recipient population by affecting the genetic composition or spreading disease (Griffith et al. 1989; Germano and Bishop 2009). We used the best available data to consider these issues and, after identifying an appropriate study area, balanced our decision to test translocation based on the myriad of threats throughout the entire range of the subspecies, especially habitat fragmentation. Here, we use the operational definition of translocation as moving larval individuals within a fragmented, genetically similar subpopulation, to a pond constructed with adequate surrounding upland habitat known to have supported adults as recently as 2002 (M. Allaback and D. Laabs, unpublished data). The intent was to allow larvae to undergo metamorphosis at the new pond and establish site fidelity, so that individuals would colonize the surrounding protected lands and create a self-sustaining breeding population.

The 26-ha Willow Canyon Unit of the Santa Cruz Long-toed Salamander Ecological Reserve (Reserve) was established in 2009 and is owned and managed by the California 
Department of Fish and Wildlife (Fig. 1). Topography is hilly with two seasonal springs dominated by oak woodlands and patches of coastal scrub, willow riparian and non-native Acacia. In 2012, the Resource Conservation District of Santa Cruz County constructed a pond on the Reserve $(36.964045,-121.875488$, elevation 65 m; Figs. 1 and 2). The pond appeared to provide suitable breeding habitat based on a sufficient hydro-period and supported colonization by Pacific (= Sierran) treefrog (Hyliola $\{=$ Pseudacris $\}$ regilla) and macro-invertebrates. The Seascape Uplands Pond is a productive breeding site within the known dispersal distance of $A$. m. croceum located $730 \mathrm{~m}$ offsite to the southeast (Fig. 1). Approximately 1,100 $\mathrm{m}$ to the north is the Valencia Lagoon Unit of the Santa Cruz Longtoed Salamander Ecological Reserve, where the subspecies was discovered in 1954 (Russell and Anderson 1956). However, there is limited or no upland habitat connectivity between Valencia Lagoon and Willow Canyon because of residential development.

The Valencia Lagoon Unit was established in 1973 and today consists of a 2.4-ha strip of land situated between Bonita Road and State Highway 1, as well as a patchwork of undeveloped residential lots in the nearby area (Fig. 1). Following various modifications of the original marsh that was compromised by the construction and expansion of State Route 1, a 1.5 ha freshwater impoundment was completed in 1978 that has provided a consistent breeding site referred to as Valencia Lagoon (36.972423, -121.879883, elevation $34 \mathrm{~m}$ ). Maximum depth reaches nearly $2 \mathrm{~m}$ and it generally dries by late summer (M. Allaback and T. Kasteen, personal observation). The upland at the Valencia Lagoon Unit is densely vegetated with a mixture of native and non-native plants, primarily willow riparian and oak woodland with some nonnative green wattle (Acacia decurrens), black cottonwood (Populus balsamifera), and Monterey pine (Pinus radiata). The portion of the Valencia Lagoon Unit supporting upland habitat situated immediately adjacent to the intersection of Bonita Drive and Encino Drive is considered critical, because it is unlikely that adult $A$. $m$. croceum are able to complete their breeding migration beyond approximately $300 \mathrm{~m}$ from Valencia Lagoon, mainly due to residential housing that creates barriers to terrestrial movements (Fig. 1; Allaback and Laabs 2003). Since the Valencia Lagoon Unit is constrained by State Route 1 and habitat conversion to the south, it is effectively isolated from all other potential $A$. $m$. croceum habitat. However, the best available genetic information indicates common ancestry between Valencia Lagoon and Seascape animals, which places the Willow Canyon Unit within the same subpopulation (W. Savage, University of Massachusetts Lowell, unpublished data).

Between State Route 1 and the Valencia Lagoon Unit is a drainage channel that supports a narrow band of mostly willow riparian habitat extending approximately $700 \mathrm{~m}$ along the south edge of the highway between Freedom and Rio Del Mar Boulevards. The California Department of Transportation (Caltrans) periodically removes emergent marsh vegetation from the dry channel in the late summer prior to the onset of winter rains. Approximately 75 m east of Valencia Lagoon, a 0.1-ha seasonal pool forms in the drainage channel during the winter that typically dries in May or June. It is the only pool along the entire drainage channel with a sufficient hydro-period to provide breeding habitat for A. m. croceum (M. Allaback and T. Kasteen, personal observation). However, the channel receives erratic pulse flows during rain events and dries rapidly each spring even during years of above average rainfall, regularly stranding larvae prior to transformation (M. Allaback and T. Kasteen, personal observation). Furthermore, late spring rains frequently wash a portion of the larval cohort up to $350 \mathrm{~m}$ or more out of the deep pool and down the channel into a series of shallow pools that dry rapidly such that no larvae survive without intervention. 


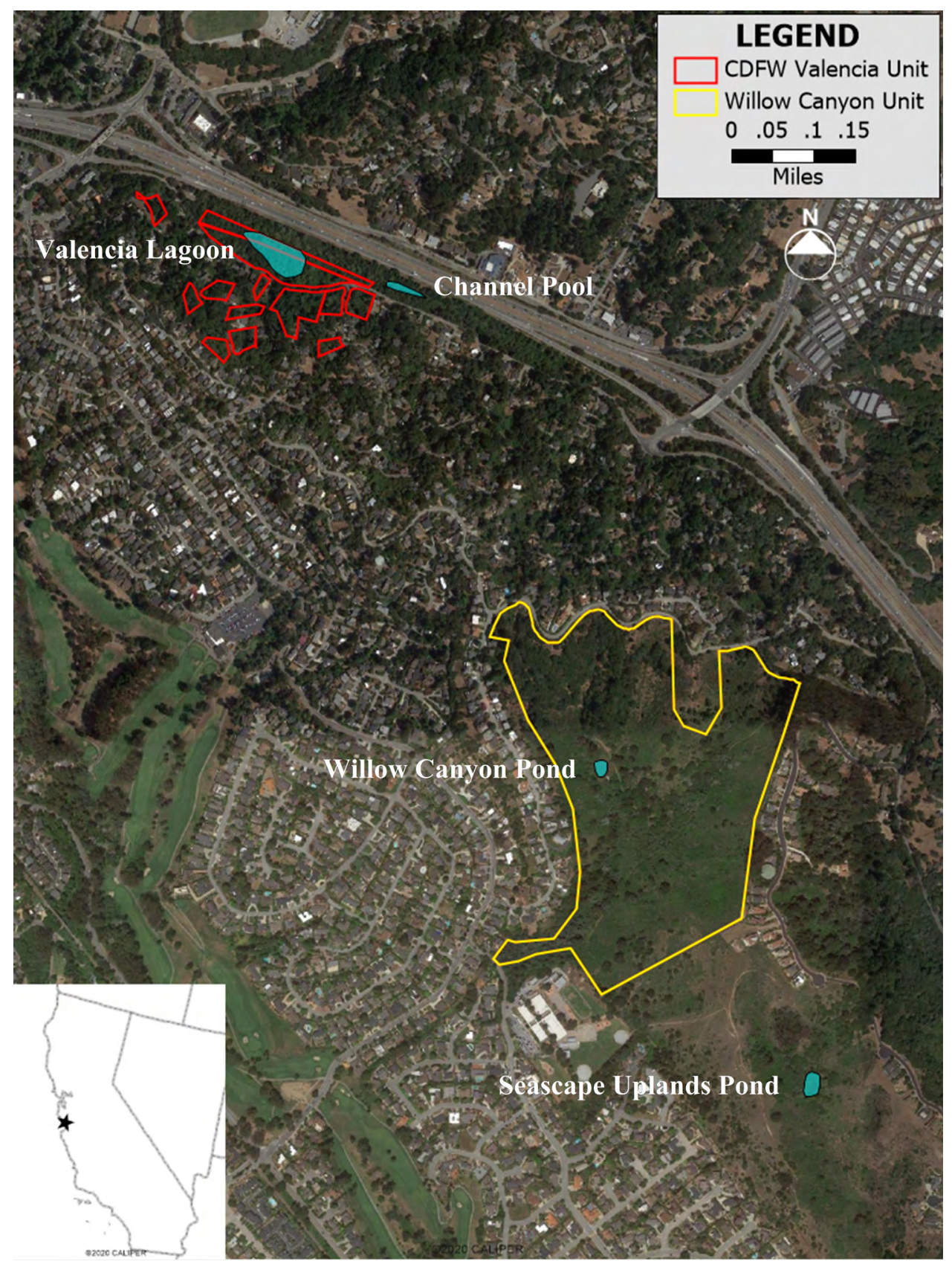

Figure 1. Aerial image of CDFW Santa Cruz Long-toed Salamander Ecological Reserve - Valencia Lagoon Unit (northern grouping of red circles) and Willow Canyon Unit, Santa Cruz County, CA, USA. 


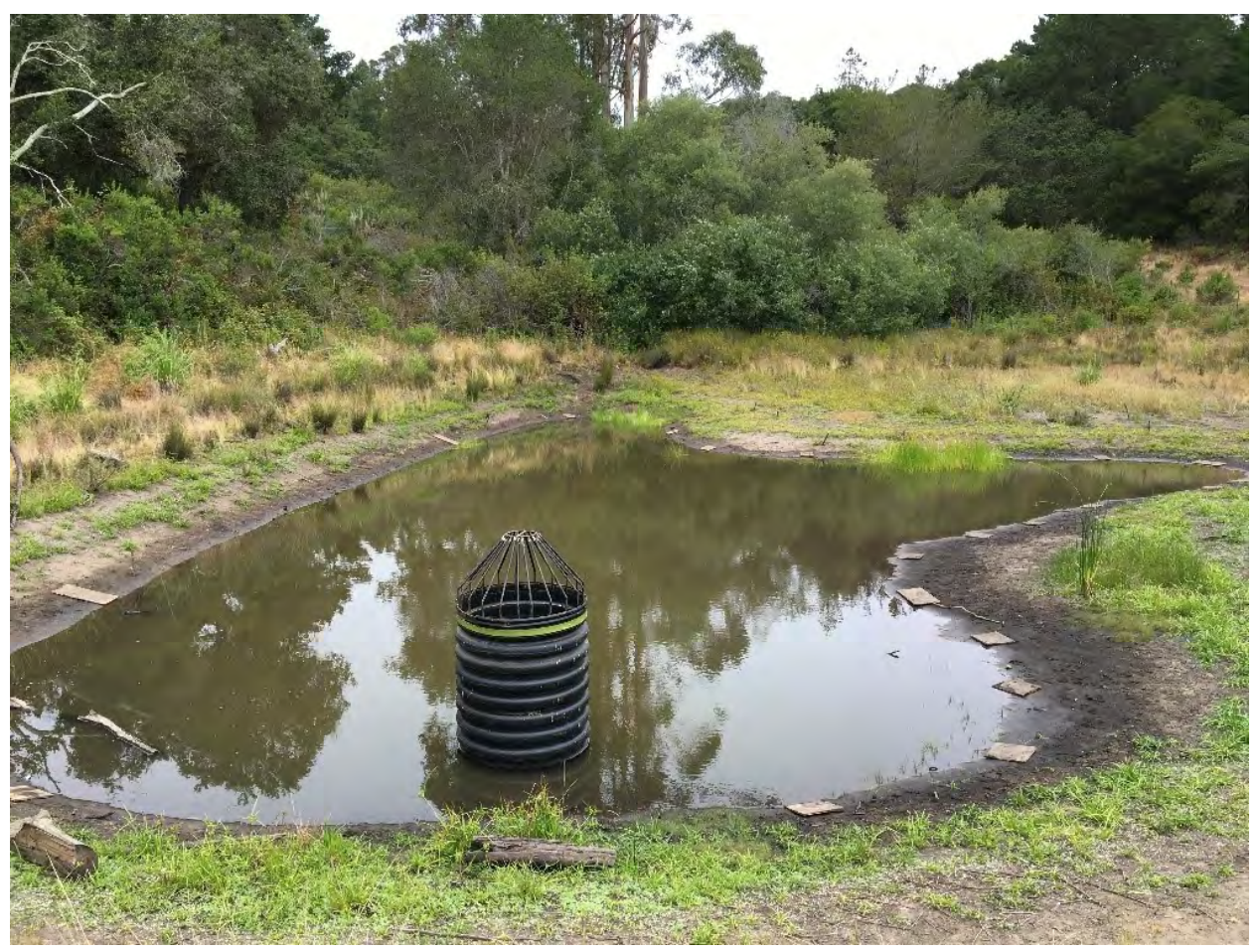

Figure 2. Coverboards placed at highwater line around Willow Canyon Pond (facing north), Santa Cruz County, CA, USA, 28 June 2016.

Beginning in 2013, we surveyed the constructed pond at Willow Canyon annually using long-handled dipnets and seines and did not detect evidence of $A$. $m$. croceum breeding. From 2016-2018, after aquatic sampling at the Willow Canyon Pond was negative, we translocated larvae from the Valencia drainage channel to the Willow Canyon Pond as both a salvage and recovery effort. Two or three sampling visits were required each year beginning in May through early June, with at least six days between visits. Within 90 minutes of initial capture, individuals were transported to the Willow Canyon Pond; allowed to acclimate in shallow water for 30-60 minutes; and released at 2-6 separate locations along the perimeter within patches of emergent vegetation dominated by spikerush (Eleocharis $\mathrm{sp}$.).

A total of 947 larvae were translocated (300 in 2016, 144 in 2017, and 503 in 2018). On 21 June 2016, 18 days after that year's final translocation of 136 larvae (average length 69.2 mm TL, $n=15)$, we began a coverboard study to determine if translocated larvae reached metamorphosis. We placed 26 small, $1.3 \mathrm{~cm}$ thick plywood coverboards $(20$ boards $=30.5$ $\mathrm{cm} \times 30.5 \mathrm{~cm}$; six boards $=30.5 \mathrm{~cm} \times 61 \mathrm{~cm}$ ) around the perimeter of the pond at the highwater line (Fig. 2). From 21 June through 11 August 2016, the coverboards were inspected every morning and periodically adjusted perpendicularly to near the edge of high water as the pond dried. When encountered, post-metamorphic juveniles were measured, weighed, and moved approximately 10-30 $\mathrm{m}$ to an area of moist leaf litter in nearby uplands under mature willow (Salix sp.) and coast live oak (Quercus agrifolia) canopy. 
Forty-six post-metamorphic juveniles (i.e., metamorphs) were detected under coverboards from 22 June through 5 August 2016 (Figs. 3 and 4). Metamorphs were observed during 27 of the 52 days coverboards were monitored, with the highest number $(n=4)$ on 17 and 21 July 2016, near the midpoint of the field study (Fig. 4). Metamorphs were detected under 22 of the 26 cover board locations, and in all cardinal directions, but were most common on the southeastern (i.e., downstream) locations (Fig. 5). Individual metamorphs averaged $66.6 \mathrm{~mm}$ total length (range 47-86; $\mathrm{n}=34$ ), $36.4 \mathrm{~mm}$ snout-vent length (range 22-46; $\mathrm{n}=34$ ), and $1.3 \mathrm{~g}$ (range $0.4-2.6 ; \mathrm{n}=32$ ) (Fig. 6). Coverboards were removed on 11 August 2016, following six days without any observations of metamorphs and while the water depth was approximately $35 \mathrm{~cm}$.

During subsequent years, translocations were conducted from 11 May 2017 through 8 June 2017 and 8-16 May 2018. To monitor larval development at the recipient (=Willow Canyon) pond, aquatic sampling was conducted after the final transfer each year. Aquatic sampling on 23 April 2019 yielded an abundance of larvae, indicating that unassisted breeding occurred at Willow Canyon Pond. On 27 September 2019, 20 metamorphs were observed under woody debris (Fig. 7). This juvenile aggregation was consistent with behavior reported by Alvarado (1967) and Anderson (1967). We believe this indicates that resident (previously translocated) A. m. croceum successfully bred and metamorphosed at the Willow Canyon Unit for the first time in 2019. On 21 May 2020, larvae were readily detected for the second consecutive year, and we assumed that a self-sustaining breeding population was established at the recipient pond that could be periodically monitored in the future.

We used minimally invasive field methods to translocate $A$. m. croceum larvae from an atypical, at-risk breeding location to a constructed pond on a Reserve near the northern limit of the subspecies' range. Results of the coverboard study revealed useful data regarding the timing of metamorphosis, including body mass at transformation. Data suggest that metamorphs dispersed in all directions, and distribution was uneven and may be influenced

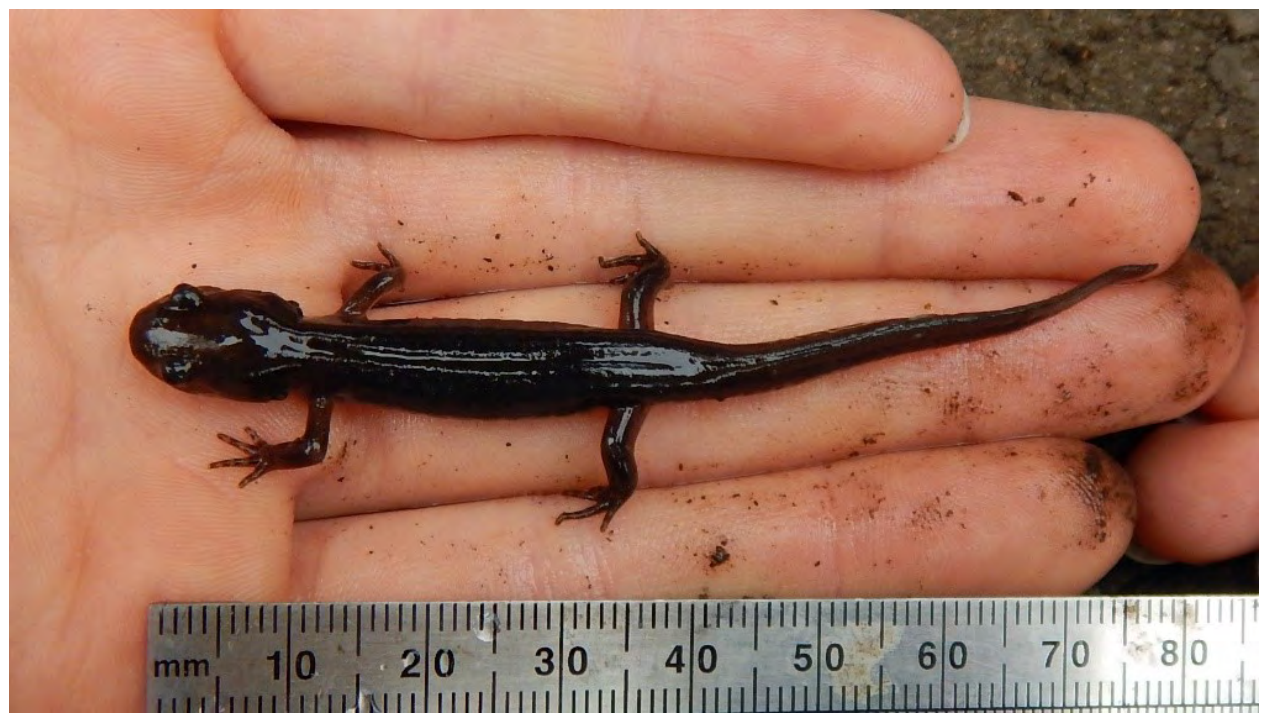

Figure 3. Newly metamorphosed Santa Cruz long-toed salamander, Willow Canyon Pond, Santa Cruz County, CA, USA, 30 July 2016. 


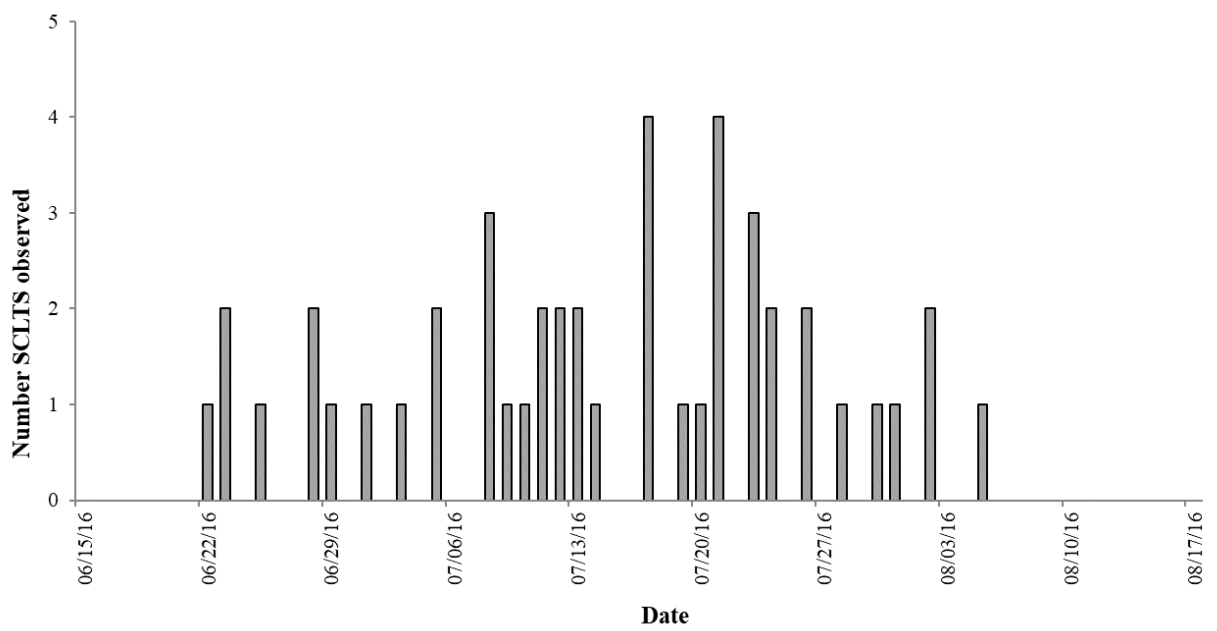

Figure 4. Number of Santa Cruz long-toed salamander (SCLTS) metamorphs observed by date under coverboards at Willow Canyon Pond, Santa Cruz County, CA, USA, 2016.

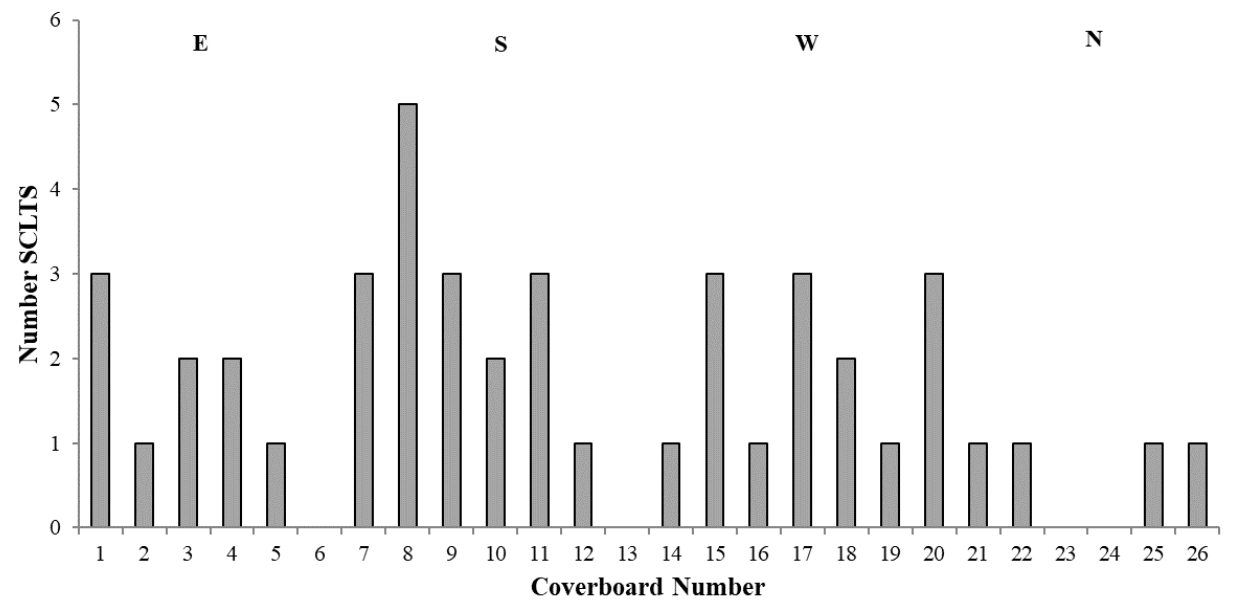

Figure 5. Frequency and distribution of Santa Cruz long-toed salamander (SCLTS) metamorphs by coverboard at the Willow Canyon Pond, Santa Cruz County, CA, USA, 2016 (approximate cardinal directions indicated).

by perimeter cover near the high-water line (see: Petranka 1998) or the topography around the pond basin. Given the consistent number of detections under small coverboards, we speculated that emerging metamorphs circle portions of the high-water line seeking cover or perhaps gentle topography, a behavior that may influence the direction of dispersal and may also have important management implications. The Willow Canyon Pond was not naturally colonized within five years after construction, despite being situated in optimal uplands with limited habitat connectivity to a known breeding pond. A variety of site-specific factors likely affect the time period and dispersal distance required for A. m. croceum to colonize new locations, especially in a fragmented landscape. 


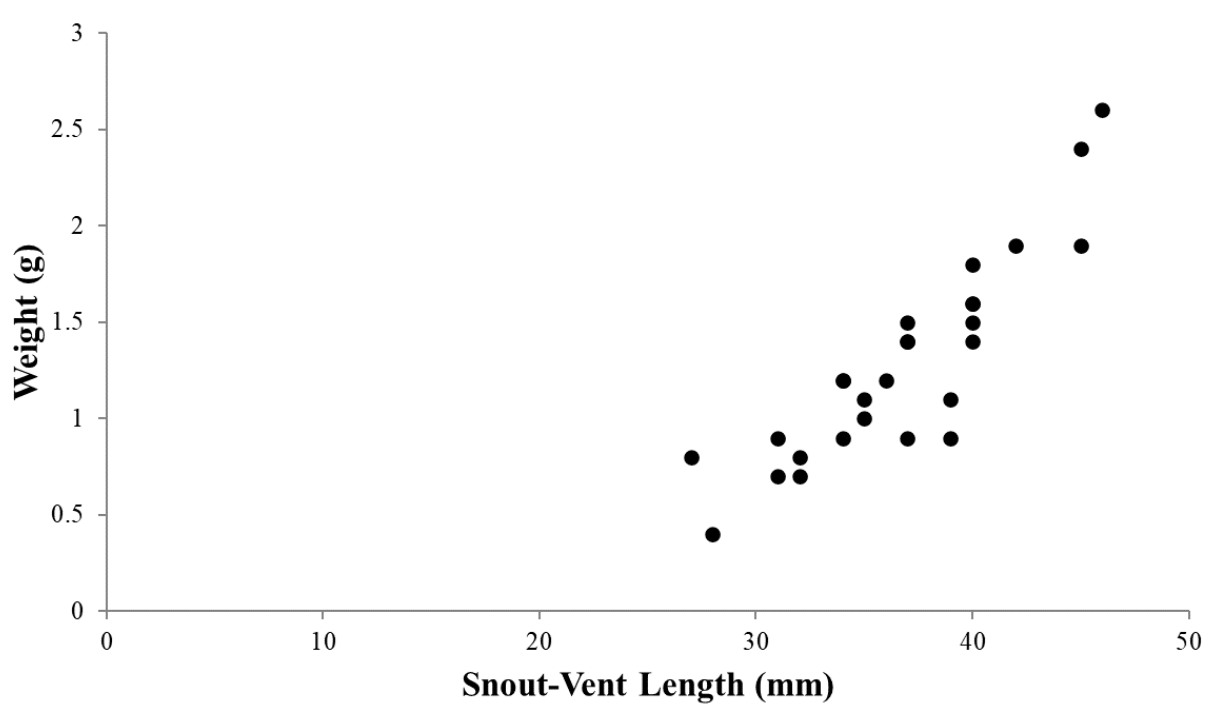

Figure 6. Weight and length of Santa Cruz long-toed salamander metamorphs, Willow Canyon Pond, Santa Cruz County, CA, USA, 2016.

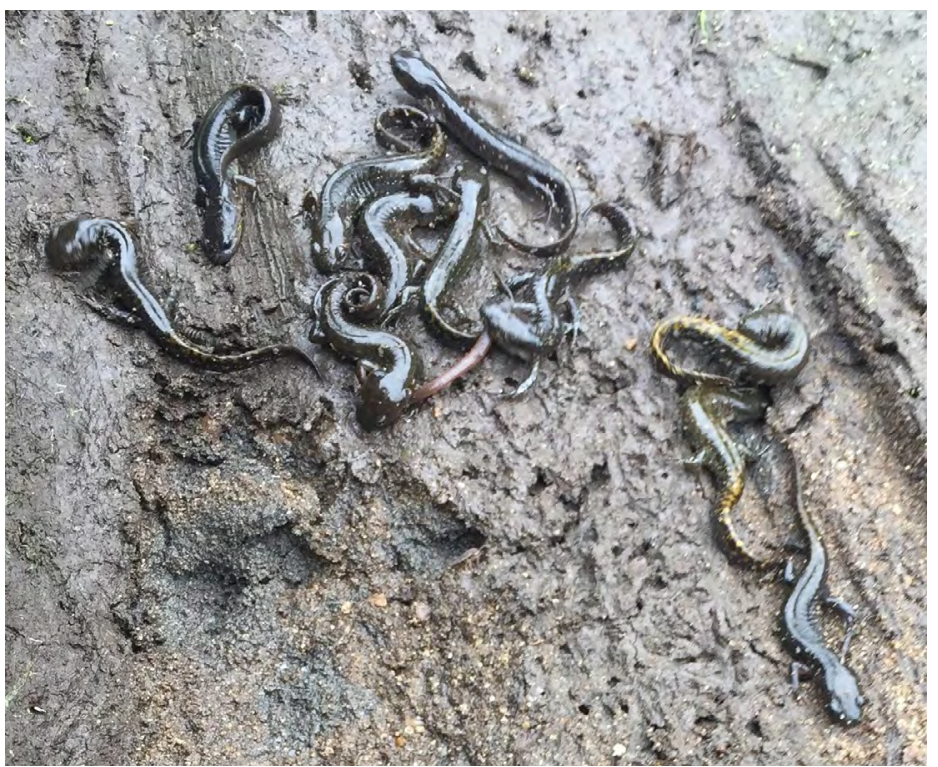

Figure 7. Santa Cruz long-toed salamander metamorphs found under a $\log$ adjacent to Willow Canyon Pond, Santa Cruz County, CA, USA, 27 September 2019.

We demonstrated that translocating an average of $300+A$. m. croceum larvae from consecutive breeding seasons appeared to establish a self-sustaining population within three years, thereby satisfying the success criteria put forth in Germano and Bishop (2009). This is in contrast with Semlitsch (2002) who recommended 10,000-50,000 eggs be moved over several years. In some cases, this large a collection effort may be infeasible, and curtail or eliminate efforts to reestablish populations. If future translocation studies are conducted, the 
recipient location should be protected in perpetuity and not only contain a seasonal pond with a six to eight-month hydro-period, but sufficient upland habitat that provides connectivity to other breeding locations (Anderson 1967; USFWS 1978; Griffith et al. 1989; Dodd and Seigel 1991). Although we do not know if one season of translocation is sufficient to establish a self-sustaining population for $A$. m. croceum, we recommend that future efforts also translocate for consecutive years, since multiple generations of different aged adults would more quickly establish a robust breeding population and may also increase genetic diversity. However, our results suggest that a single round of larval translocations may be sufficient to initiate breeding of $A$. m. croceum, since individuals may reach sexual maturity within two years after metamorphosis (Anderson 1967). It is therefore possible that individuals from the first- and/or second-year translocations successfully recruited and returned to breed. While pond construction is typically expensive and requires periodic maintenance, the traditional methods used to implement and monitor this translocation effort did not require significant time or expense, especially with multiple volunteers. Given the paucity of breeding sites throughout its range, particularly on protected lands, pond construction linked with salvage and translocation may be a viable tool for future $A$. m. croceum recovery efforts.

\section{ACKNOWLEDGMENTS}

This effort was made possible with funding from the Wildlife Conservation Board (property acquisition), Natural Resources Conservation Service and State Coastal Conservancy (pond design and permitting), the State Water Resources Control Board and the US Fish and Wildlife Service Coastal Program (pond construction). We thank Caltrans for access and the California Department of Fish and Wildlife for both access and support in this study. Although the California Department of Fish and Wildlife provided partial funding, nearly all time and labor was volunteered by the authors. C. Hamza provided field assistance in 2017. We also thank staff at the United States Fish and Wildlife Service and California Department of Fish and Wildlife for input on study design including D. Kodama, C. Jones, G. Martinelli, and L. Patterson, as well as two anonymous reviewers that improved the manuscript.

\section{LITERATURE CITED}

Allaback, M. L., and D. M. Laabs. 2003. Effectiveness of road tunnels for the Santa Cruz long-toed salamander. Transactions of the Western Section of the Wildlife Society 38/39:5-8.

Alvarado, R. H. 1967. The significance of grouping on water conservation in Ambystoma. Copiea 1967:667-668.

Anderson, J. D. 1967. A comparison of the life histories of coastal and montane populations of Ambystoma macrodactylum in California. The American Midland Naturalist 77:323-355.

Bury, R. B., and S. B. Ruth. 1972. Santa Cruz long-toed salamander: survival in doubt. Herpetological Review 4:20-22.

Bury, R. B., C. K. Dodd, and G. M. Fellers. 1980. Conservation of the amphibia of the United States: a review. United States Fish and Wildlife Service, Resource Publication, No. 134, Washington D.C., USA.

Dodd, C. K., and R. A. Seigel. 1991. Relocation, repatriation, and translocation of amphibians and reptiles: are they conservation strategies that work? Herpetologica 47:336-50. 
Germano, J. M., and P. J. Bishop. 2009. Suitability of amphibians and reptiles for translocation. Conservation Biology 23:7-15.

Griffith, B., J. M. Scott, J. W. Carpenter, and C. Reed. 1989. Translocation as a species conservation tool: status and strategy. Science 245:4777-4800.

Petranka, J. W. 1998. Salamanders of the United States and Canada. Smithsonian Institution Press, Washington, D.C., USA.

Russell, R. W., and J. D. Anderson. 1956. A disjunct population of the long-nosed [sic.] salamander from the coast of California. Herpetologica 12:137-140.

Savage, W. K. 2008. Landscape genetics and phylogenetic relationships in the Ambystoma macrodactylum species complex. Thesis, University of California, Davis, CA, USA.

Semlitsch, R. 2002. Critical elements for biological based recovery plans of aquatic-breeding amphibians. Conservation Biology 16:619-629.

Stebbins, R. C., and S. M. McGinnis. 2012. Field Guide to Amphibians and Reptiles of California. University of California Press, Berkeley, CA, USA.

U.S. Fish and Wildlife Service (USFWS). 1977. Santa Cruz long-toed salamander (Ambystoma macrodactylum croceum) recovery plan. U.S. Fish and Wildlife Service, Portland, OR, USA.

U.S. Fish and Wildlife Service (USFWS). 1978. Endangered and threatened wildlife and plants, proposed determination of critical habitat for the Santa Cruz long-toed salamander. Federal Register 43:26759-26760.

U.S. Fish and Wildlife Service (USFWS). 1999. Santa Cruz long-toed salamander (Ambystoma macrodactylum croceum) draft revised recovery plan. Region 1, U.S. Fish and Wildlife Service, Portland, OR, USA.

U.S. Fish and Wildlife Service (USFWS). 2019. 5-year review Santa Cruz long-toed salamander (Ambystoma macrodactylum croceum). U.S. Fish and Wildlife Service, Ventura Field Office, Ventura, CA, USA.

Submitted 28 September 2020

Accepted 3 November 2020

Associate Editor was K. Smith 